\title{
Spiritual Well-Being of Russian Orthodox and Evangelical Christians: Denominational Features
}

\author{
Konstantin S. Divisenko*(D), Alexei E. Belov and Olga V. Divisenko
}

Citation: Divisenko, Konstantin S., Alexei E. Belov, and Olga V. Divisenko. 2021. Spiritual Well-Being of Russian Orthodox and Evangelical Christians: Denominational Features. Religions 12: 392. https://doi.org/ $10.3390 /$ rel12060392

Academic Editors: Bradley Nassif and Tim Grass

Received: 19 March 2021

Accepted: 24 May 2021

Published: 28 May 2021

Publisher's Note: MDPI stays neutral with regard to jurisdictional claims in published maps and institutional affiliations.

Copyright: (c) 2021 by the authors. Licensee MDPI, Basel, Switzerland. This article is an open access article distributed under the terms and conditions of the Creative Commons Attribution (CC BY) license (https:/ / creativecommons.org/licenses/by/ $4.0 /)$.
Sociological Institute, Federal Center of Theoretical and Applied Sociology, Russian Academy of Sciences, 190005 St. Petersburg, Russia; alexeibelov2001@gmail.com (A.E.B.); olga.tupahina@gmail.com (O.V.D.)

* Correspondence: k.divisenko@socinst.ru

\begin{abstract}
Till the early 2000s, the Russian "religious renaissance" caused by the collapse of the USSR had been characterized by the rapid growth of religiosity. However, these spiritual changes had been occurring within the Russian Orthodox church and among Evangelical Christians in different manners. Evangelical communities are still relatively small; however their members are highly devoted to their traditions. Meanwhile, Orthodox religiosity is primarily characterized by the nominal self-identification of believers and relatively low level of religious practices' intensity. The article presents the study results (2017-2019) of the spiritual well-being of Orthodox and Evangelical Christians and its basic confessional and social determinants. The results demonstrate a strong correlation between the enchurchment level and the spiritual well-being level. The authors place particular emphasis on the role of religious coping that determines subjective well-being. The analysis confirmed that the positive ways of religious coping are determined by the regularity of religious practices and the believers' social capital. We interpret the peculiarities of Orthodox and Evangelicals' spiritual well-being in the light of differences between their church life's arrangements which are defined by the believers' practical religiosity and social capital.
\end{abstract}

Keywords: religiosity in Russia; spirituality; Orthodoxy; Protestantism; Evangelical Christians; subjective well-being; spiritual well-being scale; religious coping; Brief RCOPE Scale; enchurchment

\section{Introduction}

"Religious renaissance" in Russia in the late 1980s can be interpreted as the consequence of the nonlinear and cyclic nature of Russian society's secularization (Sinelina 2009, pp. 15-17). This process was occurring along with contradictory tendencies: the significant number of conversions to traditional and nontraditional religions on the one hand, and the formation of the phenomenon of the so-called "faith with no affiliation" on the other (Davie 2006, p. 274). The latter has been predetermined by the high level of the Russians' cultural self-identification with Orthodoxy, which does not suggest a deep perception of Christian dogmas and institutionalized practices. Along with it, one can observe the formation of such the phenomenon as "nondenominational Christianity", when theologically and ethically people agree with Christian teachings but do not formally belong or affiliate themselves with any church.

In the 20th century, Russian Protestantism had been experiencing qualitative transformations as well: traditional Protestantism in Russia with its ethnic backgrounds (Lutheranism, Anglicanism, Methodism, Reformed churches etc.) was supplemented with Evangelical movements and churches (Baptist, Pentecostal, Charismatic, power-evangelical churches and missions etc.) (Lunkin 2015, p. 298). The affiliation with non-Orthodox confessions started to be identified not by traditional or ethnic foundations but with a person's free choice. The primary role belongs to the search for a new or alternative kind of spirituality. These phenomena probably represent the consequence of the transformation of religion's function in modern society when the church is primarily supposed to respond to people's special spiritual needs and demands. 
According to various sociological surveys, most Russians identify themselves with Orthodoxy. In 1990, only $25 \%$ of the population considered themselves Orthodox, while in 1997-54\% (Chesnokova 2005, p. 8). In 2012, 72\% of Russia's population affiliated themselves with Orthodox church. However in 2014 this number reduced to $68 \%$ (Enchurchment of Orthodox Christians 2014) and got relatively stable since then. The given dynamics was accompanied with a relatively low level of religious participation: in the 2014 survey, $21 \%$ of the respondents indicated that they practically never go to church, $61 \%$-that they never partake of the Eucharist, 79\% - that they never fast, 30\% - that they practically never pray, and $58 \%$ - that they have never read the Gospel or other scriptures. Due to this feature of Russian culture, self-identification seems to be a doubtful criterion of religiosity among the Orthodox. The academic discussion on the sociological dimension of religiosity and the problem of the latter's criteria that started 30 years ago stays relevant to the present day (Divisenko 2016; Lebedev et al. 2020; Prutskova et al. 2020).

The results of the Levada Center surveys suggest that the number of active/practising Christians in Russia has not significantly changed in the last two decades. There was a certain tendency to grow of the number of the respondents who attend church at least once a month (7\% in 2003, 14\% in 2013 and 12-18\% in 2018-2019) (Public Opinion 2020, p. 121). The number of the respondents having intentions to observe Lent has never changed much $-23-25 \%$ on average (ibid). Likewise, the number of the Orthodox who partake of the Eucharist once a month or oftener was not significantly changing from 1991 till 2014 (2-6\% of those who consider themselves the Orthodox) (Emelyanov 2018, p. 35). Therefore, according to different evaluations, the number of active/practising Orthodox Christians varies from 4\% to 25\% (Sigareva and Sivoplyasova 2019; Emelyanov 2018, p. 46).

According to the results of representative surveys, the number of Protestants in Russia is about $1 \%$ (often in combination with Catholics). However, the expert assessment and calculation methodology that consider the number of registered religious organizations demonstrate that the number of Protestants (including Evangelicals) varies from 1 to 2.5 million people, i.e., 1.5\% (Kargina 2014; Ivanenko 2018). It is noteworthy that in contrast to some Russians who consider themselves Orthodox but are not baptized or even do not believe in the existence of God, those who affiliate with some Protestant church or confession are usually active/practising Christians. In contrast to Orthodox parishes, membership in Protestant churches is typically stable. At the same time, there is a greater communal control and an excellent opportunity for the implementation of "grassroots" initiatives (Simonov 2018).

Mass surveys indicate that the religious faith in public opinion in last decades is seen as the significant factor affecting daily life. According to the representative survey conducted by the Russian Public Opinion Research Center in 2016, 55\% of the Russians consider that religion helps them in their daily life. It is noteworthy that compared to 1990, this number doubled (Fyodorov 2016, pp. 7-8). Likewise, the number of the respondents who rely on God in their daily life and feel His presence nearly doubled: 25\% in 1991 and $47 \%$ in 2016 (ibid). One may assume that religious beliefs are even more significant in the common system of self-regulation for practising Christians. However, this assumption is yet to be approved.

The Soviet ideological system practically excluded the development of Russian sociology of religion from world science. Many scales and questionnaires developed by American and European sociologists and psychologists of religion (Hill and Hood 1999) were unavailable to Russian scholars for a long time. For this reason, the problem of the interrelation of subjective well-being and individual religiosity and spirituality has been insufficiently studied. The major goal of our research project ("Spirituality and Subjective Well-being: The Methods of Sociological Research", Russian Foundation for Basic Research (RFBR), No 16-06-00138) was designed to partially close this gap via adaptation and validation of the most significant measures for their following use in Russian cultural context. In this paper, we would like to sum up our major discoveries. 
Usually, empirical studies of subjective well-being in the context of spirituality and religiosity investigate the level of well-being among religious respondents and correlating variables and/or analyse the impact of spirituality/religiosity on life satisfaction. In the case of practising Christians, the significant determinant of life perception and evaluation is the sense of God's presence and His assistance in daily life, which relates to theological and ethical foundations of Christianity. The sense of belonging to the divine is closely connected with the sense of the meaning of life and positively correlates with subjective well-being (Jung 2015; Casas et al. 2009).

Several studies clearly demonstrate that religious faith positively affects the people in hardships or with serious diseases, i.e., those who experience objective severe and negative factors (e.g., Daaleman 1999; Hasson-Ohayon et al. 2009). Religious and spiritual beliefs influence the existential narratives of the sick people and helps them cope with hardships caused by diseases (Finocchiaro et al. 2014; Sacco et al. 2014; Duran et al. 2020). It is empirically approved that the variable characterising one's satisfaction with own religiosity and spirituality provides a significant impact on Christian respondents' overall evaluation of their life (Wills 2009).

It is noteworthy that culture is another significant factor determining both subjective well-being of Christians and validity of methodological tools (Lavrič and Flere 2008; Shiah et al. 2016). The study of the quality of life in Eastern countries (collectivist cultures) demonstrated that it is often hard to apply western methods to local contexts due to their individualistic foundations and values (Kwon 2008).

Our analysis of various social studies of subjective well-being in the context of religiosity and spirituality has led us to a number of conclusions that are important for conducting such studies in the context of Russian religiosity. It can be claimed that subjective wellbeing must be studied as the multidimensional phenomenon using of various scales that relate to cognitive and affective components, such as religious/spiritual/subjective wellbeing, life satisfaction and its different aspects, presence of negative and positive emotions, etc. Within the sociological analysis, it is also important to determine the behavioural component of well-being, for instance, the interrelation between subjective well-being and religious practice in the course of coping with various hardships. As long as research on subjective well-being is based not only on the respondents' evaluation of their own life but also on the objective indicators, it is important within empirical studies to control the influence of such factors as gender, age, ethnicity, education, marital status, intensity of religious practices, frequency of prayer, etc. The connection between religiosity and subjective well-being can be either immediate or depending on other factors (so-called "well-being mediators"), such as the sense of purpose, practical affiliation with a religious community, sense of hope, self-evaluation, values (both individual and cultural), etc.

The following section briefly presents the results of our studies of Christians' spiritual well-being and its correlation with religiosity and the determinants of religious coping (religiously framed adaptive strategies that reduce stress).

\section{Results}

\subsection{Christians' Spiritual Well-Being}

Spirituality as the highest level of a person's formation and self-direction (Leontiev 2009 , p. 217) is a phenomenon that is hard to operationalise within empirical studies without unavoidable reduction. However various tests and scales are being used to analyse spirituality. Index of Core Spiritual Experiences by J. D. Kass et al. (1991) is applied to describe spiritual experiences that lead to the formation of an individual's belief in the existence of God. Spiritual Assessment Inventory by Hall and Edwards (2002) aims to analyse one's spiritual maturity that depends on his or her awareness of God and quality of relations with Him. Mysticism Scale by R. W. Hood (1975) emphasizes analysing of an individual's experience of the transcendent, i.e., how he or she perceives "the spiritual world". 
Our research used Spiritual Well-Being Scale (SWBS) (Paloutzian and Ellison 1982) based on the two-dimensional spirituality model. The first (religious well-being (RWB)) reflects a person's experience of the connection with God. The second (existential wellbeing $(E W B))$ is expressed in his or her satisfaction with life and whether a person has positive emotions in how he or she perceives his or her life experience.

The SWBS consists of the twenty items, ten of which relate to the RWB subscale and the other ten to the EWB subscale. The religious and existential well-being level is defined by the sum of points on the respective items (from 10 to 60), while the spiritual well-being scale score results from the summation of the two subscales (from 20 to 120, accordingly). The higher scores - the higher well-being level. It should be noted that the normative scores on the scales depend on various factors, such as gender, age, religious or confessional affiliation, etc. (Bufford et al. 1991). The evaluation of well-being level can also be calculated via the comparison with conventional norms. Religious and existential well-being levels are evaluated in complying with the following rates: low (10-20), average (21-49), and high (50-60) accordingly. The rates for the spiritual well-being scale are 20-40, 41-99 and 100-120 accordingly (Fabbris et al. 2017).

We translated SWBS into Russian and adapted it for use in the interdenominational comparative perspective - in relation to the Orthodox and the Protestants (see Appendix A). Relying on the literature analysis, materials from Christian websites and the biographical interviews with Christians that we had conducted previously, we adapted the Russian version of the scale to the contemporary peculiarities of Russian Christian environments. This qualitative data allowed us to select the universal words and phrases to bring the scale items into accordance with the spiritual experience of the believers. For instance, we could not use the literal translation of "relationship with God" in case of the Orthodox, that is used in several SWBS items ("I have a personally meaningful relationship with God", "I do not have a personally satisfying relationship with God", "My relationship with God helps me not to feel lonely" and some others). Due to the interviews, we found that the Orthodox speak about the presence of God in their life. Therefore, in these items, we asked them about the presence of God instead of "relationship with God".

SWBS scores for negatively worded items $(1,2,5,6,9,12,13,16$ and 18) were reversed before statistical analysis. Descriptive statistic was used for the analysis of participants' socio-demographic characteristics, religious behaviour, and for the SWBS scores. The internal consistency and reliability of the SWBS were determined using Cronbach's $\alpha$. We used Spearman's rank correlation because of non-normal distribution of SWBS total and subscales. Due to the same reason, non-parametric tests (Mann-Whitney U-test and Kruskal-Wallis test) were used to compare SWBS scores between independent groups.

The invitation to participate in the survey was primarily addressed to practising Christians via social media and Christian e-newsletters. In 2017, 560 respondents took part in the survey, 158 of which are the Orthodox Christians. As to the Protestants (402 respondents), $37.3 \%$ are members of Pentecostal churches, 28.9\% are Evangelical Christians-Baptists, 9\% are Evangelicals, and $24.9 \%$ are members of independent communities not affiliated with any Christian denominational unions and associations. Few respondents are Lutherans, Adventists, Presbyterians, members of Messianic communities, etc. The quantitative emphasis on the Protestants is caused by our desire to reveal differences not only between the Orthodox and Protestants, but also within the Protestant/Evangelical environment (between Charismatics and members of other Evangelical churches).

Most of the Orthodox respondents were women (72.8\%). As to the Evangelical Christians, $53.7 \%$ of the respondents were men. The average age was 39 (standard deviation12.6). $83 \%$ of the Orthodox respondents have higher education degrees $(56.9 \%$ among the Protestants). $52.5 \%$ of the Orthodox and $68.9 \%$ of the Evangelicals are married. $49.9 \%$ of the Protestants have two or more children (30.7\% among the Orthodox) (Table 1). 
Table 1. Participant characteristics $(n=560)$.

\begin{tabular}{ccc}
\hline Characteristic & Orthodox $(n=\mathbf{1 5 8})$ & Protestants $(n=4 \mathbf{0 2})$ \\
\hline Gender & \% & \% \\
Male & 27.2 & 53.7 \\
Female & 72.8 & 46.3 \\
Marital status & & \\
Single & 34.8 & 24.9 \\
Married & 52.5 & 68.9 \\
Divorced & 10.1 & 4.5 \\
Widowed & 2.5 & 1.7 \\
Number of children & & \\
None & 44.2 & 35.9 \\
1 & 25.1 & 14.2 \\
2 & 22.4 & 18.2 \\
3 & 6.4 & 16.2 \\
$\geq 4$ & 1.9 & 15.5 \\
Education level & & 34.6 \\
$\leq$ Post-secondary education & 13.8 & 8.5 \\
Incomplete higher education & 3.2 & 52.2 \\
Higher education & 74.1 & 4.7 \\
Academic degree & 8.9 &
\end{tabular}

The variables describing religious behaviour (frequency of church attendance, participation in sacraments and Eucharist, Bible reading, private prayer) (Chesnokova 2005) were used for measurement of religiosity (Table 2).

Table 2. Participant religious behaviour $(n=560)$.

\begin{tabular}{ccc}
\hline Frequency of & Orthodox $(n=\mathbf{1 5 8})$ & Protestants $(n=\mathbf{4 0 2})$ \\
\hline & \% & \% \\
\hline Private prayer & & \\
Less than once a month & 3.8 & 0.5 \\
Once a month & 1.9 & 1.0 \\
Once a week & 2.5 & 0.2 \\
Several times a week & 10.2 & 5.0 \\
Once a day & 35.0 & 33.3 \\
Several times a day & 46.6 & 60.0 \\
Bible reading & & \\
Never & 5.1 & 0.0 \\
A long time ago & 17.2 & 0.5 \\
Few months ago & 10.8 & 1.2 \\
Less than once a month & 9.6 & 2.7 \\
Once a month & 7.0 & 1.0 \\
Several times a month & 10.2 & 4.2 \\
Once a week & 6.4 & 6.0 \\
Several times a week & 12.7 & 19.9 \\
Daily & 21.0 & 64.4 \\
\hline
\end{tabular}


Table 2. Cont.

\begin{tabular}{ccc}
\hline Frequency of & Orthodox $(n=\mathbf{1 5 8})$ & Protestants $(\boldsymbol{n = 4 0 2})$ \\
\hline Church attendance & \% & \% \\
\hline Rare (once a few years) & 1.9 & 1.2 \\
Once per year & 3.8 & 0.5 \\
Once every three months & 5.1 & 0.0 \\
$>4$ and $\leq 11$ times per year & 9.6 & 0.5 \\
Once a month & 17.2 & 4.5 \\
Once a week & 47.8 & 42.3 \\
Several times a week & 14.6 & 51.0 \\
\hline Participation in Eucharist & & \\
Never & 3.8 & 1.2 \\
Rarely (once a few years) & 11.5 & 2.2 \\
Once per year & 7.0 & 0.7 \\
Once every three months & 10.8 & 3.5 \\
$>4$ and $\leq 11$ times per year & 15.3 & 12.4 \\
Once a month & 26.1 & 73.6 \\
Once a week & 22.9 & 5.2 \\
Several times a week & 2.5 & 1.0 \\
\hline
\end{tabular}

The proportion of participants who prayed at least once a day, and at the same time read the Bible at least once a week, attended the church once a week and partook in Eucharist at least every month among Protestant and Orthodox respondents was 71.4\% and $25.9 \%$, respectively. This active/practising group of participants we, conventionally, denote as churched believers.

The validity of the Spiritual Well-Being Scale was determined by correlation analysis with other subjective well-being scales and tests-Purpose in Life Test (PL) (Crumbaugh and Maholick 1981; Leontiev 2000) and Satisfaction with Life Scale (SL) (Diener et al. 1985; Osin and Leontiev 2020). It was found strong correlation between scores of SWBS and PL $(\rho=0.684, p<0.000)$ and SWBS and SL $(\rho=0.611, p<0.000)$, indicating good validity. The high level of internal consistency between SWBS items (Cronbach's $\alpha=0.854$ ) has been confirmed as well (Table 3).

Table 3. Correlation and internal consistency of the scales.

\begin{tabular}{cccccc}
\hline Variables & RWB & EWB & SWB & PL & Cronbach's $\alpha$ \\
\hline Religious well-being (RWB) & 1 & & & & 0.757 \\
Existential well-being (EWB) & 0.520 & 1 & & & 0.813 \\
Spiritual well-being (SWB) & 0.777 & 0.920 & 1 & & 0.854 \\
Purpose in Life Test (PL) & 0.490 & 0.694 & 0.684 & 1 & 0.923 \\
Satisfaction with Life Scale (SL) & 0.343 & 0.664 & 0.611 & 0.675 & 0.817 \\
\hline
\end{tabular}

The means and standard deviations of participants' RWB, EWB and SWB scores were $55.6 \pm 5.8,50.5 \pm 8.2$ and $106.2 \pm 12.3$, respectively. A statistical distinction between the well-being of Orthodox and Protestant participants was found. RWB, EWB and SWB scores for Orthodox Christians are lower ( $p<0.000$, Mann-Whitney U-test) (Table 4). 
Table 4. Descriptive analysis of the Spiritual Well-Being Scale.

\begin{tabular}{cccc}
\hline Scale & Denomination & Mean \pm Standard Deviation & Median \\
\hline \multirow{2}{*}{ Religious well-being } & Orthodoxy & $53.6 \pm 7.2$ & 56 \\
& Protestantism & $56.4 \pm 5.0$ & 59 \\
\hline \multirow{2}{*}{ Existential well-being } & Orthodoxy & $47.3 \pm 9.1$ & 50 \\
& Protestantism & $51.8 \pm 7.4$ & 54 \\
\hline \multirow{2}{*}{ Spiritual well-being } & Orthodoxy & $101.0 \pm 13.5$ & 105 \\
& Protestantism & $108.2 \pm 11.2$ & 111 \\
\hline
\end{tabular}

As to the representatives of various Protestant churches, no significant difference between spiritual well-being levels has been discovered. The Orthodox Christians with a high level of spiritual well-being (100 + scores) are $64.3 \%$, and the Evangelicals- $82.8 \%$. Comparing representatives of different genders and levels of education, no significant difference of well-being levels has been found neither among the Orthodox nor among the Evangelicals. As to the Evangelicals, there is a weak direct correlation between the age and RWB $(\rho=0.119 ; p=0.017)$ and EWB $(\rho=0.182 ; p=0.000)$ and, therefore, SWB $(\rho=0.177$; $p=0.000)$. EWB, as well as SWB scores, are significantly higher among married Orthodox, compared with single or divorced ( $p$ of Kruskal-Wallis test is 0.010 and 0.031 , respectively). The same connection with the marital status is confirmed among the Evangelicals $(p=0.000)$. Furthermore, the Evangelical parents have a higher level of existential and spiritual wellbeing $(p=0.000)$; no such connection has been discovered among the Orthodox.

We found a statistically significant correlation between all scores of religious behaviour variables (private prayer, Bible reading, church attendance, participation in Eucharist) and scores of RWB for all participators. EWB scores correlate directly with scores of religious behaviour variables only for Protestants (Table 5).

Table 5. Correlation between religious behaviour and spiritual well-being (Spearman's rank correlation).

\begin{tabular}{ccccccc}
\hline \multirow{2}{*}{ Variables } & \multicolumn{3}{c}{ Orthodox } & \multicolumn{3}{c}{ Protestants } \\
\cline { 2 - 7 } & RWB & EWB & SWB & RWB & EWB & SWB \\
\hline Religious well-being & 1 & $0.338^{* * *}$ & $0.723^{* * *}$ & 1 & $0.548^{* * *}$ & $0.780^{* * * *}$ \\
Existential well-being & $0.338^{* * *}$ & 1 & $0.852^{* * *}$ & $0.548^{* * *}$ & $1^{* * *}$ & $0.936^{* * *}$ \\
Private prayer & $0.327^{* * *}$ & 0.022 & $0.207^{* *}$ & $0.318^{* * *}$ & $0.305^{* * *}$ & $0.337^{* * *}$ \\
Bible reading & $0.300^{* * *}$ & 0.023 & $0.191^{*}$ & $0.262^{* * *}$ & $0.268^{* * *}$ & $0.297^{* * *}$ \\
Church attendance & $0.371^{* * *}$ & -0.003 & $0.223^{* *}$ & $0.141^{* *}$ & $0.214^{* * *}$ & $0.202^{* *}$ \\
Participation in Eucharist & $0.228^{* *}$ & -0.020 & $0.136^{* *}$ & $0.167^{* *}$ & $0.195^{* *}$ & $0.199^{* * *}$ \\
\hline
\end{tabular}

Note. RWB-Religious Well-being Scale, EWB-Existential Well-being Scale, SWB-Spiritual Well-being Scale. ${ }^{*} p<0.05$; ${ }^{* *} p<0.01 ;{ }^{* * *} p<0.001$.

The churched believers among Orthodox participants had a higher level only of religious well-being than other Orthodox respondents (mean of scores was 56.3 and 52.7, respectively). As to the more active/practising subgroup of the Protestants, all the three scales demonstrate the significantly higher levels of well-being (mean of RWB, EWB, and SWB scores for churched subgroup and other Protestants were 57.1/54.5, 53.0/48.7 and 110.2/103.2, respectively).

The confirmed significant positive correlation between the level of practical religiosity and the level of spiritual well-being, regardless of confessional affiliation, had raised the question on the search for religious mechanisms of coping that affect subjective well-being.

\subsection{Religious Coping}

Mechanisms of coping with life obstacles significantly depend on a person's interpretation of adverse events, resulting from a person's worldview and practical daily life logic. Religion and spirituality serve as serious resources that usually let people cope with hardships in everyday life and also during crises and rough periods (Divisenko and Belov 2017). 
To conduct the comparative study of religious coping among the Orthodox and the Protestants, we translated into Russian and tested Brief RCOPE. The particular coping methods are consolidated into the two groups within this measure-positive and negative (Pargament et al. 1998; Pargament et al. 2000). The first one unites the methods that allow religious persons to cope with stress with no adverse consequences. Among these are forgiveness, spiritual support, re-evaluation of adverse events and other managing forms that help people live through adverse circumstances, form a sense of spiritual unity with others, and sustain the positive world perception. Negative coping methods are characterized by the perception of negative events as punishment and are based on such feelings as offence, regret, lack of connection with God and doubts about God's omnipotence and love. Negative coping may serve as the evidence for one's inner spiritual tension and struggle that is likely to have negative consequences for a person due to the transformation of stress into a cognitive pattern of interpreting various events of personal history and experience.

Participants' characteristics and Brief RCOPE scores were analysed by descriptive statistics. Correlations of Brief RCOPE scores with independent variables scores were analyzed using Pearson's correlation coefficient. We conducted stepwise regression to determine the unique contribution of the variables included in the study on the Brief RCOPE subscales.

In 2018, 409 Christians took part in our religious coping study: 176 Orthodox and 233 Protestants (Evangelicals-13.3\%; Evangelical Christians-Baptists-15.9\%; Pentecostals$44.2 \%$; members of other churches-26.6\%). The invitation to participate in the survey was also (as in 2017) addressed to practising Christians via social media and Christian e-newsletters. We sent the request to fill in the questionnaire to those who had shared their email in the 2017 study.

Most Orthodox respondents are women (77.3\%). The average age was $38.81 .2 \%$ have higher education degrees. $51.7 \%$ are married, $28.4 \%$ are single, $53.3 \%$ have child/children. More than half (54.9\%) of the Protestant respondents are women. The average age was 42 . The largest proportion have higher education degrees (58.8\%), 66.9\% are married, $21.5 \%$ are single, $67.0 \%$ have child/children (Table 6).

Table 6. Participant characteristics $(n=409)$.

\begin{tabular}{ccc}
\hline Characteristic & Orthodox $(n=\mathbf{1 7 6})$ & Protestants $(\boldsymbol{n}=\mathbf{2 3 3})$ \\
\hline Gender & $\%$ & $\%$ \\
Male & 22.7 & 45.1 \\
Female & 77.3 & 54.9 \\
Marital status & & \\
Single & 28.4 & 21.5 \\
Married & 51.7 & 66.9 \\
Divorced & 11.4 & 7.7 \\
Widowed & 5.1 & 3.0 \\
Other & 3.4 & 0.9 \\
Number of children & & \\
None & 46.7 & 33.0 \\
1 & 23.3 & 16.3 \\
2 & 18.6 & 23.2 \\
3 & 7.4 & 17.6 \\
$\geq 4$ & 4 & 9.9 \\
Education level & & \\
$\leq$ Post-secondary education & 12.0 & 30.0 \\
Incomplete higher education & 6.8 & 11.2 \\
Higher education & 73.8 & 54.9 \\
Academic degree & 7.4 & 3.9 \\
\hline
\end{tabular}


Most Orthodox respondents are active/practising Christians. $17.0 \%$ of them go to church several times a week, $44.9 \%$-once a week, $15.9 \%$-several times a month. $27.8 \%$ partake of the Eucharist once a week or oftener, $21.6 \%$ - once a month or oftener, but not weekly, $18.8 \%-5-11$ times a year. $38.6 \%$ pray several times a day, $39.8 \%$-at least once a day. $18.8 \%$ read the Bible on a daily basis, $11.9 \%$ - several times a week. $9.7 \%$ read the Bible at least once a month, $17 \%$-several times a month. As to Protestant religious behaviour patterns, $53.6 \%$ pray several times a day, $34.8 \%$-at least once a day, $10.3 \%$ several times a week. $62.7 \%$ read the Bible daily, $24.9 \%$ at least once a week. $53.2 \%$ go to church several times a week, $36.5 \%$-once a week. $65.7 \%$ partake of the Eucharist once a month or more frequently, but not weekly, $10.7 \%$-weekly or several times a week, $21.5 \%$-less frequently than once a month (Table 7). Notably, the largest proportion of the Orthodox (44.9\%) had only "a few" acquaintances in church; the according share of acquaintances among the Protestants was only $6.9 \%$. The proportion of the participants acquainted almost with everyone was $9.7 \%$ and $50.2 \%$ for the Orthodox and the Protestants, respectively. The number of friends in the church was similarly differentiated: church members represent the main circle of friends for $54.9 \%$ of the Protestants and only for $12.5 \%$ of the Orthodox. There was no significant difference in the distribution of responses about critical life events over the past year by the confession. About $55 \%$ of respondents have experienced significant hardships, and about $40 \%$-insignificant hardships.

Table 7. Participant religious behaviour and general characteristics $(n=409)$.

\begin{tabular}{ccc}
\hline Frequency of & Orthodox $(\boldsymbol{n = 1 7 6 )}$ & Protestants $(\boldsymbol{n}=\mathbf{2 3 3})$ \\
\hline & \% & \% \\
\hline Private prayer & & \\
Less than once a month & 5.1 & 0.4 \\
Once a month & 2.8 & 0.9 \\
Once a week & 2.8 & 0.0 \\
Several times a week & 10.8 & 10.3 \\
Once a day & 39.8 & 34.8 \\
Several times a day & 38.6 & 53.6 \\
Bible reading & & \\
Never & 3.4 & 0.0 \\
A long time ago & 15.3 & 1.7 \\
Few months ago & 8.0 & 0.4 \\
Less than once a month & 12.5 & 3.4 \\
Once a month & 3.4 & 2.6 \\
Several times a month & 17.0 & 4.3 \\
Once a week & 9.7 & 8.2 \\
Several times a week & 11.9 & 16.7 \\
Daily & 18.8 & 62.7 \\
\hline Church attendance & & \\
Rare (once a few years) & 5.1 & 3.0 \\
Once per year & 5.1 & 1.3 \\
Once every three months & 4.0 & 0.4 \\
4 and $\leq 11$ times per year & 8.0 & 1.7 \\
Once a month & 15.9 & 3.9 \\
Once a week & 44.9 &
\end{tabular}


Table 7. Cont.

\begin{tabular}{|c|c|c|}
\hline Frequency of & Orthodox $(n=176)$ & Protestants $(n=233)$ \\
\hline & $\%$ & $\%$ \\
\hline \multicolumn{3}{|l|}{ Participation in Eucharist } \\
\hline Never & 6.8 & 2.1 \\
\hline Rarely (once a few years) & 12.5 & 3.0 \\
\hline Once per year & 5.7 & 1.3 \\
\hline Once every three months & 6.8 & 5.2 \\
\hline$>4$ and $\leq 11$ times per year & 18.8 & 12.0 \\
\hline Once a month & 21.6 & 65.7 \\
\hline Once a week & 24.4 & 8.6 \\
\hline Several times a week & 3.4 & 2.1 \\
\hline \multicolumn{3}{|l|}{$\begin{array}{l}\text { Proportion of acquaintances in } \\
\text { church }\end{array}$} \\
\hline No acquaintances & 16.5 & 1.7 \\
\hline A few & 44.9 & 6.9 \\
\hline Many & 27.8 & 41.2 \\
\hline Acquainted almost with everyone & 9.7 & 50.2 \\
\hline \multicolumn{3}{|l|}{ Friends in church } \\
\hline Main circle of friends & 12.5 & 54.9 \\
\hline Some friends and acquaintances & 43.8 & 40.3 \\
\hline Almost none & 33.0 & 1.7 \\
\hline Hard to say & 9.7 & 3 \\
\hline \multicolumn{3}{|l|}{$\begin{array}{c}\text { Critical life events over the past } \\
\text { year }\end{array}$} \\
\hline None & 2.3 & 5.2 \\
\hline Insignificant hardships & 40.3 & 39.9 \\
\hline Significant hardships & 56.3 & 54.9 \\
\hline
\end{tabular}

The results of the study demonstrate that the respondents mostly use positive religious coping. Normative mean scores ranged from 17 to 21 for the Positive religious coping subscale (PRC) and 8 to 14 for the Negative religious coping subscale (NRC) (Pargament et al. 2011). In our study, mean PRC subscale scores were 23.43 and 24.91 for the Orthodox, and the Protestants, respectively, significantly higher than the normative mean. Mean NRC subscale scores (13.72 and 13.25 for the Orthodox, and the Protestants, respectively) accorded with the results of the other studies. Table 8 displays the descriptive analysis of the Brief RCOPE.

Table 8. Descriptive analysis of the Brief RCOPE subscales.

\begin{tabular}{cccc}
\hline Subscales & Denomination & Mean & Standard Deviation \\
\hline Positive religious coping (PRC) & Orthodoxy & 23.43 & 4.22 \\
& Protestantism & 24.91 & 2.90 \\
\hline \multirow{2}{*}{ Negative religious coping (NRC) } & Orthodoxy & 13.72 & 4.08 \\
& Protestantism & 13.25 & 3.49 \\
\hline
\end{tabular}

The methods of religious coping in our research do not depend on basic social and demographical characteristics (gender, age, education, marital status, etc.). The correlation between Brief RCOPE subscales and other variables included in the study is presented in Table 9. 
Table 9. Correlation between Brief RCOPE subscales and the variables included in the study.

\begin{tabular}{ccccc}
\hline Variables & \multicolumn{2}{c}{ Orthodox $(\boldsymbol{n}=\mathbf{1 7 6})$} & \multicolumn{2}{c}{ Protestants $(\boldsymbol{n}=\mathbf{2 3 3})$} \\
\cline { 2 - 5 } & PRC & NRC & PRC & NRC \\
\hline Positive religious coping (PRC) & 1 & $0.237^{* *}$ & 1 & $0.197^{* *}$ \\
Negative religious coping (NRC) & $0.237^{* *}$ & 1 & $0.197^{* *}$ & 1 \\
Private prayer & $0.538^{* * *}$ & 0.104 & $0.445^{* * *}$ & -0.126 \\
Bible reading & $0.347^{* * *}$ & 0.083 & $0.369^{* * *}$ & -0.103 \\
Church attendance & $0.472^{* * *}$ & $0.221^{* *}$ & $0.150^{*}$ & -0.099 \\
Participation in Eucharist & $0.430^{* * *}$ & $0.172^{*}$ & $0.239^{* * *}$ & -0.059 \\
Proportion of acquaintances in church & $0.253^{* *}$ & 0.103 & $0.247^{* * *}$ & -0.100 \\
Proportion of friends in church & $0.231^{* *}$ & -0.056 & $0.295^{* * *}$ & -0.056 \\
Religious socialization & 0.083 & 0.029 & -0.067 & $-0.204^{* *}$ \\
Critical life events & 0.103 & $0.294^{* * *}$ & $0.148^{*}$ & $0.174^{* *}$ \\
\hline
\end{tabular}

${ }^{*} p \leq 0.05$; $^{* *} p \leq 0.01{ }^{* * *} p \leq 0.001$.

There was a statistically significant direct correlation between PRC subscale and private prayer, Bible reading, church attendance, participation in Eucharist, the proportion of acquaintances in church, the proportion of friends in church for all the respondents. In addition, the positive religious coping was connected with experience with life troubles in the past year among the Protestants. As to the Orthodox, the NRC subscale was directly correlated with church attendance, participation in Eucharist, critical life events over the past year, and to the Protestants-with critical life events and the lack of primary religious socialization (the index based on such variables as the significance of faith for parents, the religiosity of each parent and the frequency of attending Sunday school in childhood).

A stepwise linear regression analysis was performed to explore the factors affecting the positive and negative forms of religious coping. We analysed each form of religious coping and separately for the Orthodox and the Protestants. As religious coping predictors we considered religious behaviour variables, primary religious socialization, number of acquaintances and friends in church, and the number of serious life problems during the last year. The models summary and coefficients are shown in Tables 10 and 11.

Table 10. Stepwise regression analysis on prediction of positive religious coping.

\begin{tabular}{|c|c|c|c|c|c|}
\hline \multicolumn{6}{|c|}{ Orthodox Participants } \\
\hline Independent Variables & B & SE & $\beta$ & $t$ & $p$ \\
\hline constant & 21.178 & 1.820 & & 11.636 & 0.000 \\
\hline Private prayer & 1.127 & 0.300 & 0.327 & 3.759 & 0.000 \\
\hline Church attendance & 0.845 & 0.250 & 0.294 & 3.383 & 0.001 \\
\hline \multicolumn{6}{|c|}{ Note: $R=0.560, R^{2}=0.314$, Adjusted $R^{2}=0.305, F=34.3, p<0.001$} \\
\hline \multicolumn{6}{|c|}{ Protestant Participants } \\
\hline Independent Variables & B & SE & $\beta$ & $t$ & $p$ \\
\hline constant & 3.740 & 0.192 & & 19.432 & 0.000 \\
\hline Private prayer & 0.161 & 0.034 & 0.310 & 4.705 & 0.000 \\
\hline Bible reading & 0.054 & 0.019 & 0.187 & 2.880 & 0.004 \\
\hline Proportion of acquaintances in church & 0.094 & 0.042 & 0.139 & 2.216 & 0.028 \\
\hline Proportion of friends in church & 0.099 & 0.049 & 0.126 & 2.006 & 0.046 \\
\hline
\end{tabular}


Table 11. Stepwise regression analysis on prediction of negative religious coping.

\begin{tabular}{|c|c|c|c|c|c|}
\hline \multicolumn{6}{|c|}{ Orthodox Participants } \\
\hline Independent Variables & B & SE & $\beta$ & $t$ & $p$ \\
\hline constant & -0.576 & 2.598 & & -0.222 & 0.825 \\
\hline Critical life events & 2.238 & 0.553 & 0.303 & 4.047 & 0.000 \\
\hline Church attendance & 0.913 & 0.231 & 0.330 & 3.955 & 0.000 \\
\hline Proportion of friends in church & -1.574 & 0.510 & -0.256 & -3.084 & 0.002 \\
\hline \multicolumn{6}{|c|}{ Note: $R=0.416, R^{2}=0.173$, Adjusted $R^{2}=0.157, F=10.4, p<0.001$} \\
\hline \multicolumn{6}{|c|}{ Protestant Participants } \\
\hline Independent Variables & B & SE & $\beta$ & $t$ & $p$ \\
\hline constant & 1.347 & 0.174 & & 7.727 & 0.000 \\
\hline Religious socialization & -0.142 & 0.042 & -0.219 & -3.401 & 0.001 \\
\hline Critical life events & 0.186 & 0.056 & 0.221 & 3.326 & 0.001 \\
\hline Private prayer & 0.102 & 0.041 & 0.165 & 2.478 & 0.014 \\
\hline \multicolumn{6}{|c|}{ Note: $R=0.336, R^{2}=0.113$, Adjusted $R^{2}=0.100, F=9.1, p<0.001$} \\
\hline
\end{tabular}

Regression analysis demonstrated that in the case of all the respondents PRC score was defined by the frequency of private prayer. In addition, the frequency of Church attendance for Orthodox, the frequency of Bible reading, number of acquaintances and friends for the Protestants were statistically significantly related to participators' positive religious coping.

Critical life events over the past year were found as a predictor of negative religious coping for all the respondents. The negative forms of religious coping, in the case of the Orthodox, are associated with the more frequent church attendance and lack or low number of friends among church members. As to the Protestants, the negative forms of coping are affected by lack of primary religious socialization and low frequency of prayer. It should be noted, that although the $R^{2}$ value was low in two models of negative religious coping, the $p$ values of the $F$ test were less than 0.001 , showing a strong correlation of the interpretative power of the models. However this finding requires a deeper study of the negative religious coping factors.

\section{Discussion and Conclusions}

The significant direct connection between enchurchment (as the active participation in private and church religious practices) and spiritual well-being, discovered in the course of our study, regardless of the confessional affiliation, led to the conclusion that practical religiosity plays a positive role in participants' perception of their own life.

The study of the Christians' religious coping has confirmed the importance of religious beliefs in dealing with serious life events/crises. As initially supposed, the differences in spiritual life are partly due to the varying degrees of involvement in the church community, which is a priori determined by the confessional dispensation. Thus, this has been affirmed that the social capital (number of friends and acquaintances in church) promotes positive methods of religious coping.

It is noteworthy that there is the significant limitation of our research. The use of social media and Christian e-newsletters for recruiting participants in our studies determined the samples consisted of practising and active Christians. The majority of them lived in large cities and had higher education degrees. It probably explains the high scores for the religious, spiritual well-being and positive religious coping. We consider that it is not right to apply these results to other believers' groups.

We can agree with the opinion that "today religiosity fulfils the functions of social solidarity and social consolidation, lost by the state and not yet formed by civil society" (Ryzhova 2017, p. 58). Trends of the inversion of Orthodoxy into a civil religion in modern Russia are partly based on the peculiarities of Russian Orthodox spirituality. Mother Maria Skobtsova identified several types of piety that have historically developed in Orthodoxy; 
among them the two most "spiritually dead" are "Synodal" and "Ritualistic" (Skobtsov 2001). The first is associated with nationalism and the "great-power Russian idea", the second emphasizes external formalistic rituals to the detriment of the inner experience of the sacred. Both types are oriented primarily towards tradition and form, with the Gospel (as 'message of Christ') and its understanding by believers in worship and spiritual life relegated to the background. For this reason, future researches may focus on explaining confessional differences in spiritual well-being by the different role of the Gospel in the spiritual life of Christians. It may be assumed, that while Evangelical Christians yearn to have the Gospel at the centre of their spiritual life, many Orthodox Christians, as Bradley Nassif notes, are "surrounded by theological riches but living in spiritual poverty" (Nassif 2021). However, the connection between religiosity, involvement in the church community (social capital), and spiritual well-being among representatives of various churches requires further comparative studies.

Author Contributions: Conceptualization, K.S.D., A.E.B., and O.V.D.; methodology, K.S.D., and A.E.B.; formal analysis, K.S.D.; investigation, K.S.D., A.E.B., and O.V.D.; data curation, K.S.D., A.E.B., and O.V.D.; writing, K.S.D., A.E.B., and O.V.D.; translation, A.E.B. All authors have read and agreed to the published version of the manuscript.

Funding: This article received no external funding.

Institutional Review Board Statement: Not applicable.

Informed Consent Statement: Informed consent was obtained from all subjects involved in the study.

Data Availability Statement: The research project did not originally assume to share raw data with third parties.

Conflicts of Interest: The authors declare no conflict of interest.

\section{Appendix A}

Table A1. Russian version of the Spiritual Well-Being Scale.

\begin{tabular}{cl}
\hline Item & Russian Translation \\
\hline 1. & Мне не приносит утешение молитва, когда я обращаюсь к Богу наедине. \\
2. & Я точно не знаю, зачем я живу. \\
3. & Я верю, что Бог любит меня и заботится обо мне. \\
4. & Я воспринимаю жизнь как некий положительный опыт. \\
5. & Я полагаю, что Бог-это некая безличная высшая сила, для которой моя \\
6. & повседневная жизнь безразлична. \\
7. & У меняерен в своем будущем. \\
8. & Я вполне доволен и удовлетворен своей жизнью. \\
9. & Я не чувствую, что Бог дает мне силы и поддерживает меня. \\
10. & В целом я доволен тем, как складывается моя жизнь. \\
11. & Я ощущаю поддержку и участие Бога в трудных обстоятельствах моей жизни. \\
12. & Я не особенно доволен своей жизнью. \\
13. & Обращение к Богу не приносит мне умиротворения. \\
14. & Я оптимистично смотрю на своё будущее. \\
15. & Ощущение присутствия Бога позволяет мне чувствовать себя не одиноким. \\
16. & Моя жизнь полна невзгд и страданий. \\
17. & Я чувствую себя лучше всего, когда переживаю непосредственную связь с \\
18. & Богом. \\
19. & Вера в Бога влияет на моё ощущение благополучия. \\
20. & Я верю, что моя жизнь имеет смысл.
\end{tabular}

Note: The odd-numbered items correspond to the items of Religious Well-being subscale, and the even-numbered items correspond to the items of Existential Well-being subscale. 


\section{References}

Bufford, Rodger K., Raymond F. Paloutzian, and Craig W. Ellison. 1991. Norms for the Spiritual Well-Being Scale. Journal of Psychology and Theology 19: 56-70. [CrossRef]

Casas, Ferran, Mònica González, Cristina Figuer, and Sara Malo. 2009. Satisfaction with Spirituality, Satisfaction with Religion and Personal Well-Being among Spanish Adolescents and Young University Students. Applied Research Quality Life 4: 23-45. [CrossRef]

Chesnokova, Valentina F. 2005. Following a Narrow Path: The Process of Enchurchment of the Russian Population in the Late Twentieth Century. Moscow: Akademicheskiy Projekt. (In Russian)

Crumbaugh, James C., and Leonard T. Maholick. 1981. Manual of Instructions for the Purpose in Life Test. Abilene: Viktor Frankl Institute of Logotherapy.

Daaleman, Timothy P. 1999. Belief and Subjective Well-Being in Outpatients. Journal of Religion and Health 38: 219-27. [CrossRef]

Davie, Grace. 2006. Religion in Europe in the 21st Century: The Factors to Take into Account. European Journal of Sociology 47: 271-96. [CrossRef]

Diener, Ed, Robert A. Emmons, Randy J. Larsen, and Sharon Griffin. 1985. The Satisfaction with life scale. Journal of Personality Assessment 49: 71-75. [CrossRef]

Divisenko, Konstantin S. 2016. Straight gate in a right direction: Problem of recognizing strong group of Orthodox believers. Sotsiologicheskie issledovaniya [Sociological Studies] 10: 128-38. (In Russian)

Divisenko, Konstantin S., and Alexei E. Belov. 2017. Social studies of subjective well-being in the context of spirituality and religiosity. Sotsiologicheskiy Zhurnal [Sociological Journal] 23: 51-73. (In Russian) [CrossRef]

Duran, Songul, Dilek Avci, and Funda Esim. 2020. Association Between Spiritual Well-Being and Resilience Among Turkish Hemodialysis Patients. Journal of Religion and Health 59: 3097-109. [CrossRef] [PubMed]

Emelyanov, Nikolay N. 2018. Religiosity paradox: Where do believers come from? Monitoring of Public Opinion: Economic and Social Changes 2: 32-48. [CrossRef]

Enchurchment of Orthodox Christians. 2014. Moscow: Public Opinion Foundation. Available online: https://www.fom.ru/TSennosti/ 11587 (accessed on 20 January 2021). (In Russian)

Fabbris, Jéssika Leão, Ana Cláudia Mesquita, Sílvia Caldeira, Ana Maria Pimenta Carvalho, and Emilia Campos de Carvalho. 2017. Anxiety and Spiritual Well-Being in Nursing Students: A Cross-Sectional Study. Journal of Holistic Nursing 35: 261-70. [CrossRef]

Finocchiaro, Darlene N., Patricia A. Roth, and Cynthia D. Connelly. 2014. Spiritual Well-Being as Predictor of Quality of Life for Adults with Paraplegia. Rehabilitation Nursing 39: 285-93. [CrossRef]

Fyodorov, Valeriy. 2016. Religion in the Lives of Russians. Report presented at the conference in Russian Orthodox University of Saint John the Divine, Moscow, Russia, September 6. Moscow: Russian Public Opinion Research Center. Available online: http:/ / www.wciom.ru/fileadmin/file/reports_conferences/2016/2016-09-06-rpu.pdf (accessed on 27 August 2018). (In Russian)

Hall, Todd W., and Keith J. Edwards. 2002. The Spiritual Assessment Inventory: A theistic model and measure for assessing spiritual development. Journal for the Scientific Study of Religion 41: 341-57. [CrossRef]

Hasson-Ohayon, Ilanit, Michal Braun, Daliah Galinsky, and Lea Baider. 2009. Religiosity and Hope: A Path for Women Coping with a Diagnosis of Breast Cancer. Psychosomatics 50: 525-33. [CrossRef]

Hill, Peter C., and Ralph W. Hood. 1999. Measures of Religiosity. Birmingham: Religious Education Press.

Hood, Ralph W. 1975. The Construction and Preliminary Validation of a Measure of Reported Mystical Experience. Journal for the Scientific Study of Religion 14: 29-41. [CrossRef]

Ivanenko, Alexey I. 2018. Method of calculation of Christians in Russia (on the example of the Church of Ingria). Religiya. Tserkov'. Obshchestvo. Issledovaniya I publikatsii po teologii I religii [Religion. Church. Society: Research and publications in the field of theology and religious studies] 7: 126-49. (In Russian) [CrossRef]

Jung, Jong H. 2015. Sense of Divine Involvement and Sense of Meaning in Life: Religious Tradition as a Contingency. Journal for the Scientific Study of Religion 54: 119-33. [CrossRef]

Kargina, Inna G. 2014. Crisis influence on Protestant denominations in the contemporary Russia. Teoriya I praktika obshchestvennogo razvitiya [Theory and Practice of Social Development] 2: 100-3. (In Russian)

Kass, Jared D., Richard Friedman, Jane Leserman, Patricia C. Zuttermeister, and Herbert Benson. 1991. Health Outcomes and a New Index of Spiritual Experience. Journal for the Scientific Study of Religion 30: 203-11. [CrossRef]

Kwon, Soo-Young. 2008. Well-being and Spirituality from a Korean Perspective: Based on the Study of Culture and Subjective Well-being. Pastoral Psychology 56: 573-84. [CrossRef]

Lavrič, Miran, and Sergej Flere. 2008. The Role of Culture in the Relationship between Religiosity and Psychological Well-Being. Journal of Religion and Health 47: 164-75. [CrossRef]

Lebedev, Sergej, Mirko Blagojević, and Elena Pokaninova. 2020. Value- and reflection-based approach to indicators of Orthodox religiosity of the population. Stanovništvo 58: 47-61. [CrossRef]

Leontiev, Dmitry A. 2000. Test Smislojiznennih orientacii [Test of Life-Sense Orientations], 2nd ed. Moscow: Smysl. (In Russian)

Leontiev, Dmitry A. 2009. Spirituality. In Encyclopedia Epistemologii I philosophii nauki [Encyclopedia of Epistemology and Philosophy of Science]. Edited by Ilya T. Kasavin. Moscow: Institute of Philosophy RAS, Kanon+, pp. 217-18. (In Russian)

Lunkin, Roman N. 2015. Protestant churches in Russia. In Russia 2015. Annual Report of Observo French-Russian Analytical Center. Edited by A. Dyuben. Moscow: Noviyvek Media, pp. 298-302. (In Russian) 
Nassif, Bradley. 2021. The Evangelical Theology of the Eastern Orthodox Church. Foreword Andrew Louth. Yonkers: St. Vladimir's Seminary Press.

Osin, Evgeny N., and Dmitry A. Leontiev. 2020. Brief Russian-Language Instruments to Measure Subjective Well-Being: Psychometric Properties and Comparative Analysis. Monitoring of Public Opinion: Economic and Social Changes 1: 117-42. (In Russian) [CrossRef]

Paloutzian, Raymond F., and Craig W. Ellison. 1982. Loneliness, spiritual well-being and quality of life. In Loneliness: A Sourcebook of Current Theory, Research and Therapy. Edited by Letitia A. Peplau and Daniel Perlman. New York: John Wiley \& Sons, pp. 224-36.

Pargament, Kenneth I., Bruce W. Smith, Harold G. Koenig, and Lisa M. Perez. 1998. Patterns of Positive and Negative Religious Coping with Major Life Stressors. Journal for the Scientific Study of Religion 37: 710-24. [CrossRef]

Pargament, Kenneth I., Harold G. Koenig, and Lisa M. Perez. 2000. The many methods of religious coping: Development and initial validation of the RCOPE. Journal of Clinical Psychology 56: 519-43. [CrossRef]

Pargament, Kenneth I., Margaret Feuille, and Donna Burdzy. 2011. The Brief RCOPE: Current Psychometric Status of a Short Measure of Religious Coping. Religions 2: 51. [CrossRef]

Prutskova, Elena V., Kirill V. Markin, and Polina V. Vrublevskaya. 2020. Q-methodology in the study of "weak religiosity". Research Result. Sociology and Management 6: 184-202. [CrossRef]

Public Opinion. 2020. Moscow: Levada-Center. (In Russian)

Ryzhova, Svetlana V. 2017. Religiosity in the Context of the Culture of Trust. Sotsiologicheskiy Zhurnal [Sociological Journal] 23: 44-63. (In Russian) [CrossRef]

Sacco, Shane J., Crystal L. Park, D. P. Suresh, and Deborah Bliss. 2014. Living with heart failure: Psychosocial resources, meaning, gratitude and well-being. Heart \& Lung 43: 213-18. [CrossRef]

Shiah, Yung-Jong, Frances Chang, Shih-Kuang Chiang, and Wai-Cheong C. Tam. 2016. Religion and Subjective Well-Being: Western and Eastern Religious Groups Achieved Subjective Well-Being in Different Ways. Journal of Religion and Health 55: 1263-69. [CrossRef] [PubMed]

Sigareva, Eugenia, and Svetlana Sivoplyasova. 2019. Fertility and Religiosity in Russia: Assessing Interaction. Logos et Praxis 18: 104-15. [CrossRef]

Simonov, Igor V. 2018. Religious situation in Nizhny Novgorod region: Analytical review. Religiovedenie [Study of Religion] 3: 117-27. (In Russian) [CrossRef]

Sinelina, Yulia Yu. 2009. Cyclic Character of Secularization Process in Russia (Sociological Analysis: The end of XVII-The Beginning of XXI c.). Ph.D. thesis, Institute of Socio-Political Research RAS, Moscow, Russia. (In Russian)

Skobtsov, Marie (Mère). 2001. Les Différents Types de vie Religieuse. Available online: http:/ /www.rocorstudies.org/2017/03/31 /types-of-religious-lives/ (accessed on 12 March 2021).

Wills, Eduardo. 2009. Spirituality and Subjective Well-Being: Evidences for a New Domain in the Personal Well-Being Index. Journal of Happiness Studies 10: 49-69. [CrossRef] 